\title{
The Principal's Role and Islamic Education Learning at Muhammadiyah Elementary School during the Covid-19 Pandemic
}

\author{
Lukman Asha 1 \\ DOI: $10.35445 /$ alishlah.v13i3.931
}

\begin{tabular}{l}
\hline Article Info \\
\hline Keywords: \\
The principal's \\
management; \\
Blended learning; \\
Face-to-face learning; \\
Distance learning; \\
Teacher-student active \\
engagement
\end{tabular}

Kata kunci:

Manajemen kepala sekolah;

Blended learning; Pembelajaran tatap muka;

Pembelajaran jarak

jauh;

Keterlibatan aktif gurusiswa

\begin{abstract}
The purpose of this study was to examine the principal's managerial role in ensuring that learning processes at Muhammadiyah primary school continue desirably and effectively during the Covid-19 pandemic. Additionally, this study intended to depict learning processes in Islamic education. The principal and six Islamic education instructors were purposefully chosen as informants in this investigation. The data were gathered via documentation, observation, and interviews in order to ensure the data's credibility. Following the data collection and analysis was conducted using an interactive model. This study established that, during the covid19 epidemic, the principal used a combination of remote and face-to-face learning as a manager. Certain classes are held online and offline learning as scheduled one at a time on specific days. Through the use of such a learning system, processes and activities for instilling students' religious, moral, and social values may be conducted. Apart from offline learning, the principal and teachers collaborated with students' parents to supervise students' or children's learning processes at home. To preserve the quality of teachers, the principal encouraged teachers to participate in training on creating learning films as an engaging medium for students to comprehend the contents presented during class readily.
\end{abstract}

\begin{abstract}
Abstrak
Penelitian ini bertujuan untuk mengetahui peran manajerial kepala sekolah Madrasah Ibtidaiyah Muhammadiyah dalam melakukan upaya agar proses pembelajaran di sekolah ini tetap berjalan sesuai harapan dan efektif di tengah pandemi Covid-19. Selain itu, penelitian ini juga berusaha untuk menyajikan gambaran pelaksanaan pembelajaran pada mata pelajaran pendidikan agama Islam. Informan penelitian ini adalah kepala sekolah dan enam guru pendidikan agama Islam yang dipilih secara purposif. Data diperoleh melalui dokumentasi, observasi, dan wawancara, sehingga teknikteknik tersebut dapat menjamin kredibilitas data. Setelah data terkumpul, dilakukan analisis dengan menggunakan model interaktif. Penelitian ini secara konklusif menemukan bahwa, selama masa pandemi covid19, kepala sekolah sebagai pengelola menerapkan kombinasi pembelajaran jarak jauh dan pembelajaran tatap muka, di mana kelas-kelas tertentu pada hari-hari tertentu mengadakan pembelajaran online dan offline sesuai jadwal secara bergantian. Dengan sistem pembelajaran seperti itu, proses pembelajaran dan kegiatan untuk menanamkan karakter religius, moral, dan sosial siswa dapat berjalan sesuai rencana. Dalam blended learning, selain pembelajaran offline, agar mode pembelajaran online dapat berjalan dengan optimal, kepala sekolah dan guru bekerjasama dengan orang tua siswa untuk mengawasi proses belajar siswa di rumah. Untuk menjaga kualitas guru, kepala sekolah
\end{abstract}

\footnotetext{
${ }^{1}$ Institut Agama Islam Negeri Curup, Curup, Indonesia

Email: lukman.asha@iaincurup.ac.id
} 
memfasilitasi guru untuk mengikuti pelatihan pembuatan video pembelajaran sebagai media menarik yang membuat siswa mudah memahami materi yang diberikan selama pembelajaran.

\section{INTRODUCTION}

All events almost everywhere on the earth are booming with the Covid-19 virus, especially in Indonesia, which is currently experiencing the Covid-19 virus's rise. This phenomenon indirectly impacts school teaching and learning activities, so an offline-to-online transformation of learning mode willy-nilly has to be embodied. The preceding transformation is not easy to realise due to complex challenges faced by students and teachers. The teachers' noble task is to facilitate students in learning. Therefore, teachers must not only create a comfortable and exciting learning environment, but they must also understand and be competent at learning management both inside and outside the classroom (Warsah et al., 2021). Teachers must select and implement learning methods appropriate to the complexity of learning materials and each student's personality. However, it needs more serious efforts to realize the ideal teachers' management role in the face of learning transformation from offline to online methods.

Similar complex challenges are also faced by a Muhammadiyah elementary school which becomes the orientation of this study. During a preliminary study, the principal asserted that learning quality and teacher competencies are the benchmarks for educational institution progress, especially in this situation. If educational institutions do not immediately find ways to be adaptive, they will be eroded by times. As a result, students' parents will distrust such schools. One possible way is that the educational institutions must establish communication with parents to support students' learning management. Dealing with teaching-learning implementation during the Covid19 pandemic, Hermanto et al. (2021), in their study, explained that the school principal must be willing to make policies in the implementation of teaching and learning by applying a face-to-face mode but by limiting the number of students by health protocols. The principal, teachers, homeroom teachers, students' parents and guardians, and the local community contribute to the policy's success. According to Setyaningsih (2020), learning is done online through the distance learning policy during the pandemic. Distance learning occurs when students and teachers are not physically present at school all of the time. The implementation can be entirely remote (hybrid) or partially remote (blended). From here, the principal must carry out his responsibilities and functions as a manager to continue the learning process during the current Covid-19 virus outbreak.

Prior studies on online or distance learning have been done in the last six years. However, those studies did not focus on the school principal's managerial role. Those studies were oriented towards problems of distance or online learning. For instance, Huang (2019) research shows that teachers' cognitive, affective, and managerial (controlling) roles are more visible in face-to-face classes than in online classes. It can be noted that the online mode, if not prepared effectively, can obscure the teacher's role in these three aspects. Research conducted by Gómez-Rey et al. (2016) regarding the perceptions of teachers and students about online learning revealed that there are different points of view where teachers want and orient online learning to be carried out in the collaborative learning dimension that prioritizes interactions between teachers and students as well as between students and students, while students prefer and are oriented towards their learning. Previous studies also provide an overview of the factors that must be considered for online learning to be effective. Barberà et al. (2016) highlighted several factors such as the ability to use various online learning tools, learning motivation, goals or expectations focused on online learning, prior knowledge, and general abilities or competencies that students have. Learning from research conducted by Hernández-Lara and Serradell-López (2018), the success or fluency of online learning can be seen from the relationship between the general abilities of students and their learning outcomes, the compatibility between learning objectives and the learning process, and the compatibility between students' expectations and their satisfaction. Such linkages will greatly contribute to the effectiveness of online 
learning. According to Wei et al. (2015), increasing interactive elements supports the success of online learning. Furthermore, how responsive the teacher is to the communication built by students also determines the success of online learning (Martin et al., 2018).

To the best of the researcher's knowledge, very few studies have been conducted, especially in the school principal's managerial role in dealing with distance or online learning, especially in efforts to cope with learning during the Covid-19 pandemic. Thus, the present study seeks to fulfil this void. Drawing upon the highlighted literature gap, the crucial essence of the school principal's managerial role, which leads to the changes in teachers' innovative actions in teaching. Therefore this study seeks to find a clear and scientifically accountable picture of the principal management related to learning during the Covid-19 pandemic in order to encourage the creation of good learning quality. This study uses the Islamic education subject as the primary manifestation of the principal's managerial impacts. The implementation of good learning will fail if the principal does not properly manage it because teachers' acts of teaching will rest upon the principal's policy. In the other aspect, the principal's policy in determining whether to follow government instructions to implement the online-to-offline transformation of learning must take several factors into account, including school facilities, teachers' competencies, skills in using learning media, and the psychological condition of students and their guardians.

\section{METHODS}

This study adopted the constructivist paradigm (Creswell, 2007), which employed a qualitative approach to garner and analyze the data. The research method used was a phenomenological method with two purposes. The first purpose was to probe into the principal's managerial role in making efforts to make learning processes at Muhammadiyah elementary school continue as desired and effectively amid the Covid-19 pandemic. The second purpose of this study was to present the portrayals of learning conduction in Islamic education subjects. In this study, the principal of Muhammadiyah elementary school and six teachers were the participants. Especially for the teachers, they were selected purposively by considering that they were adequately knowledgeable and experienced. They were voluntarily willing to take part in this study as the participants.

The data were collected using documentation, interviews, online and offline observation. Documentation was done to find out the demographic information of the participants. Interviews were undertaken with the principal and the teachers. As such, interviews worked extensively to achieve the two purposes of this study. Since this was a qualitative study, pursuing data's credibility was critical (Yazan, 2015). Therefore, online and offline observations were made to reveal the data regarding the two purposes of this study. Observation data have functioned to triangulate the credulity of the interview data. Online observations were done in a way that the researcher took part in the learning platforms used by teachers during learning. Subsequently, offline observations were executed when some classes held offline classes. This was done because it was identified that this school, resting upon the principal's managerial role, had implemented a blended learning mode so that some classes with certain days were held offline.

The data gathered from documentation, observation, and interviews were analyzed using Miles' et al. (2014) interactive model comprising data collection, condensation, display, and conclusion drawing. As previously stated, the data were gathered through documentation, interviews, and online-offline observations in terms of data collection. All data from the three techniques were grouped into themes representing all data for data condensation. In terms of data presentation or display, the data were presented in a detailed review, followed by interview snippets chosen to represent all data based on the discourse being discussed. Furthermore, the data were comprehensively concluded using effective and understandable language. 


\section{FINDINGS AND DISCUSSION}

Findings and discussions are generated from the data grounded in interviews, observations, and documentation. The primary orientation of this study was to reveal the Muhammadiyah elementary school principal's managerial ways in making efforts to maintain the effective continuity of learning processes during the Covid-19 pandemic and to reveal the portrayals of learning strategies and activities of Islamic education subject. Firstly, the researcher collected documents for general demographic data continuously conducted online interviews and observations concurrently with the principal and six teachers handling the school. Online interviews were conducted via video call, and online observations were made in a way that the researcher took part in any staging of online learning executed by the teacher via several learning platforms used. Subsequently, offline observations were made when certain classes held their offline learning schedules on certain days. Before delving deeper into the description of learning management at Muhammadiyah elementary school, documentation was undertaken to find demographic information. As documented, this school had 16 teachers handling various subjects, all of whom were certified and had undergraduate education (S1) qualifications.

In terms of educational qualifications, teachers at Muhammadiyah elementary school had met professional teacher standards. As previously stated, they also had educator certification (Documentation, 12 May 2021). This aligns with Lang (2020) elucidating that certified professionalism and pedagogical competence are indicated by qualified teachers. Teachers in Muhammadiyah elementary school were considered qualified under their standard documents. They were also deemed pedagogically qualified, viewed from their background of knowledge. During an interview, the principal said, "Every teacher here teaches something new to the students in the form of professional and measurable knowledge." Of course, they had good competencies, so a teacher must be required to be professional to improve the quality of learning for Muhammadiyah elementary school students during the covid-19 pandemic by the learning management led by the school principal (retrieved from an interview with the principal, 12 May 2021). The following presentation is framed based on some themes coded from the raw data of this study. The themes extend to growing a generation with social spirit and the portrayals of Muhammadiyah elementary school's Islamic education learning processes and activities during the Covid-19 Pandemic

\section{Growing a Generation with Social Spirit}

This school used the official curriculum, K-13, in conjunction with the al-Islam Muhammadiyah curriculum. Grounded in the hand-in-hand enactment of these curriculums, this school emphasized developing students' noble character through self-habituating activities. Viewed from the paradigms endorsed, it can be seen that this school adheres to the standpoints of constructivism and behaviourism. Habituation is the embodiment of behaviourism, and the essence of socio-cultural learning embedded in the K-13 Curriculum represents the paradigm of constructivism (Banihashem et al., 2021). Regarding the aforementioned habituation, it was demonstrated by students' daily social activities during learning as guided by the teachers, such as praying in three languages, dhuha prayer, morning dzikr, muroja'ah Al-Qur'an, and tahfidz, stating the official students' appointments, singing the Indonesia Raya anthem, cheerful gymnastics, midday and asr prayers done in congregation, $S K J$ gymnastics, and flag ceremony as weekly activities. Students were also habituated by the annual programs, such as social services, the qur'ban in Idul Adhaha, Ramadhan activities conducted at the school, and study tours. Another habit taught by this school was the importance of queue while being in public places. Also, the school educated students to be self-responsible, such as washing their eating and drinking utensils. Such habituation was hoped to educate students to be good social individuals alongside maintaining cleanliness, being patient, being religious and moral (retrieved from Interview data, May 12, 2021). It can be interpreted that the principal's managerial role leads teachers and other parties at this school to guide students to build their noble character through positive habituation activities. 
Extracurricular activities applied to educate students included various forms of rhetorical extracurricular such as khutbah, practising speech in two languages, learning Islamic stories and histories, practising storytelling, and practising English speech. Sports-related extracurricular was also developed, such as karate, pencak silat, and futsal. There was also found arts-related extracurricular such as painting, singing, music, and dance. Some activities such as tahfidz, tartil, and recitation were executed regarding religious extracurriculars. It could be interpreted from the preceding data that the principal's managerial role has successfully made an ideal balance between religious and non-religious activities. As such, the principal's managerial role seems to consider the potential of students' latent competencies in learning (Nguyen, 2019). Subsequently, to educate students to be disciplined individuals, points for grading were used as the punishment system. For one semester, each student was given a capital of 250 points. If they violated the school's shared rules, their points would be deducted in accordance with the degree of violation. At the end of each semester, the remaining points could be exchanged for vouchers that students could use to make a purchase in the canteen, or they could just save it. The stages of coping with students who violated school's rules extended to oral coaching, notification letter, parent's summons via letters, and suspension (retrieved from the interview and observation data, May 12, 2021). It could be delineated that the system of grading points indicates a creative, managerial role instead of physical or psychological punishment. This is aligned with (Warsah, 2020c) emphasis on his study that the creative role of teachers depicts a good learning process as educators, and a good learning process does not implement physical punishment. Many academicians have reached a consensus that creative teachers with their facilitating and managerial roles will pave the way for shaping a good learning construction, in which old-fashioned teaching-learning paradigms can be transformed into novel ones which are contextual and oriented towards students' needs (Abraukhova, 2020; Adams, 2021; Adiguzel, 2021; Al-Dababneh, 2019; Amirova, 2020).

Each violation had its level, light, medium, or heavy. However, besides punishment, the school also rewarded students who behaved well. Monthly, the good students would receive certificates with the indicators consisting of a) students who were never absent at school, b) the neatest, c) disciplined students, d) the most diligent students in saving, e) the most creative students, and f) the students who came most early to school. There were also other incidental certificates, depending on the students' achievements or speciality in specific fields, particularly good character. There was also an award given to students at the end of each semester. This school did not apply a ranking system because the parties believed every child was special and ranked first. Each child would have the most information on each report, specific information regarding the subject they were dominant in, and particular details on the highest classification per subject (retrieved from Interview data with a teacher, 15 May 2021).

All of these activities or self-habituations were intended to shape the character of students so that after graduating from Muhammadiyah elementary school, they could be intellectually, emotionally, spiritually, and socially intelligent (Feng, 2019a). Muhammadiyah elementary school also prioritized good communication. To this end, this school provided counselling guidance for students and parents related to self-development, beginning with learning guidance, career, social, and individual development (retrieved from interview data with a teacher, May 15, 2021). Learning at school and home was designed to complement and integrate each other. This was aligned with Barclay et al. (2018), stating that there was also a parent-teacher bond in each class intended to cooperatively shape students' learning, students' development, and friendship among fellow guardians of students. As the preceding, cooperative and effective communication between the students' guardians and those of the school parties could be built up properly (Erbil \& Kocabaş, 2018).

The human resources of Muhammadiyah elementary school were chosen through a rigorous recruitment process. Employees or teaching staff must pass several tests before they are accepted to 
be hired. The first was a written test to assess knowledge competence, followed by worship practices, knowledge related to Muhammadiyah, and computer skills. Subsequently, there were also certain test periods, which lasted from 3 months to a year. Aligned with the foregoing, the second test period lasted from 6 months to a year, and the third test period lasted from a year to two years. After two years or passing the whole test period, the teaching staff would be non-permanent teachers. Once passing four years, they would be considered to be elected as permanent teachers according to the agreement from the foundation. Every year, the collaboration between the foundation and the elected teachers was evaluated. If the graph value increased year after year, the collaboration could continue. Nevertheless, if it decreased, the collaboration might end. The cooperation between teachers and the school was also applied to a contract system each year, with the contract being extended or not at the beginning of each year. The aforementioned system was applied by virtue of maintaining the school quality and credibility (retrieved from an interview with the principal, 15 May 2021).

Of course, the COVID-19 pandemic hampered the implementation of various students' routine activities as assigned by Muhammadiyah elementary school. However, due to various policy efforts made by the school principal, during this pandemic period, some routine activities were still held, monitored, and carried out from home under the supervision of students' respective parents with the monitoring guide provided by the school (Almarashdeh, 2016).

\section{The Portrayals of Muhammadiyah Elementary School's Islamic Education Learning Processes and Activities during the Covid-19 Pandemic}

This section presents field-based data garnered from the learning portrayals of Islamic education subjects. In response to the Covid-19 pandemic, the principals from many schools commonly implemented various policies to help solve the existing challenges. The policies drove the majority of teachers to implement a distance learning system. The Indonesian abbreviation was also known as PJJ (Bunga et al., 2021a, 2021b; Iskandar, 2020; Warsah, 2021). Unlike Muhammadiyah elementary school, in the first semester since July 2020, this school became one of the few that implemented a blended learning system (Bielousova, 2017) or a combination of distance learning and face-to-face learning. They applied a system that fell into 50 per cent of distance learning and 50 per cent of face-to-face learning. One at a time, classes 1,4 , and 5 held learning processes based on the regulated face-to-face schedule, and on other days, they took online learning processes. In the meantime, classes 2, 3, and 6 held the regular offline classes on Tuesdays, Thursdays, and Saturdays, with online classes on the other days (retrieved from interview data with a teacher, May 15, 2021).

Students who want to participate in face-to-face learning must have a statement letter from their guardians to do so. Still, they were also permitted to participate in online learning. During faceto-face learning, students must also adhere to strict health protocols with the requirements of wearing masks, washing hands, and keeping a safe distance from others. The number of students was limited to $50 \%$ attendance, with only three classes permitted to attend face-to-face learning each day. There were only 10-15 children in one class, with a distance of about 1-2 meters (retrieved from interview data with a teacher, May 15, 2021).

The prioritized subjects taught during face-to-face learning were the subjects for national exams, such as mathematics, Indonesian language, science, and the practice of Islamic religious education. At the same time, other subjects were taught during distance learning. For lower classes, face-to-face learning was prioritized for reading, writing, and mathematics subjects. There were reading, writing, listening, and speaking for literacy competencies. For writing, the emphasis was on how to write correctly, effectively, and proportionally. Differently, for the upper classes, the writing aspect was emphasized to make literary products from students' writings in poetry, short stories, etc. (retrieved from interview data with a teacher, May 15, 2021).

Meanwhile, when distance learning was carried out, the online media used was the Whatsapp application to deliver the materials. Sometimes, the teachers also used the Zoom meetings 
application or video calls. Most of them used Whatsapp, which was already familiar to teachers, parents, and children. Submission of materials was made via Whatsapp. If there was a practice of reading or the like, voice notes were utilized. For practical questions or assignments, a platform such as Google form was utilized (retrieved from observation data with a teacher, May 15, 2021). It could be interpreted that the teachers seem to have been sufficiently competent at utilizing technological tools based on the context of students and the existing facilities (Almarashdeh, 2016; Chang, 2016).

The implementation of distance learning at home was considered concurrent work between the teachers and students' parents to accompany, supervise, or even help teach their children (Alea, 2020; Ben, 2016). Sometimes, if some parents were too busy at work, the teachers would assist them in accompanying their children to study during distance learning. Even though children could operate their gadgets, supervision and assistance from older people were certainly needed.

While students were at home, their habituation activities were also monitored through selfhabituation control cards given to parents to monitor children when carrying out self-habituation activities at home, such as praying five times a day, praying sunnah, adding Qur'anic memorization, reading the Qur'an, muroja'ah, as well as activities related to social activities such as helping parents and friends, watching TV news, reading books, exercising in the morning, tidying up toys, and so on. Later on, the control cards would be collected at the end of the month for assessment of social and spiritual attitudes (retrieved from interview data with a teacher, May 15, 2021).

Islamic education subjects consisted of various aspects, namely aqidah, morals, fiqh, Qur'an hadith, and Islamic education history. Teaching using different methods was adapted to meet the contexts of materials and students (retrieved from interview data with a teacher, May 15, 2021). Aligned with previous research conducted by Oktaviani (2020), the material was usually delivered via Whatsapp for creed. Then the children took notes and were given a memorizing task. For example, the material was about the pillars of faith. The children would be asked to memorize the pillars of faith, and they were instructed to collect their memorisation assignments using voice notes.

Concerning the learning of moral aspect, it was held more practically, in which the teachers and parents monitored students' behaviour at school and home. In addition to the preceding, theoretical materials regarding moral values were also provided (retrieved from interview data with a teacher, May 15, 2021). The preceding data, at some point, were aligned with Warsah (2020) on his study about moral educators under rahmah character and to some extent compatible with Feng (2019b), who discussed the incorporation of moral materials in teaching and learning. Such materials were oriented towards teaching students to be responsible, well-behaved, polite in speaking, respectful for others across ages, and the like (Sulistiyo, 2020; Warsah, 2020b, 2020a). For fiqh, readings related to worship were given. Some copies of reading materials were given to students as well. Subsequently, the teachers guided students' reading activities through voice notes alongside memorizing tasks. In addition, the students were given daily control cards. For Islamic education materials related to Islamic history, the teachers used videos illustrating the stories of Islamic prophets. Continuous tasks were given to students to make summaries regarding the videos already watched. While, the material of the Qur'an and hadith, students were led to the practice of memorizing, starting from grade 1, that was to memorize juz 30, surah An-Naba. After being competent at the foregoing memorization, the memorization practice would continue to take on juz 29. At the same time, the memorization of the hadith was adjusted to each level of the students (retrieved from interview data with a teacher, May 15, 2021).

The school provided an internet data allowance for teachers. All teachers already had smartphones and laptops. To improve the quality of learning during the pandemic, teachers were engaged to participate in training about making learning videos so that they could apply alternative or interesting methods in teaching students. The movement itself was a mandatory activity for every employee and teacher. Every semester, at least every employee or teacher was required to attend one 
training program by their primary duties and responsibilities to improve the quality of each (retrieved from interview data with the principal, May 15, 2021).

\section{CONCLUSION}

The principal of Muhammadiyah primary school has implemented administrative measures since the first semester of July 2020 in response to the spread of Covid 19. This can be achieved by combining distance learning with face-to-face instruction. As a result, the school employs a system that splits instruction equally between online and face-to-face instruction. This study's focus on Islamic education is made possible by the efficiency and efficacy of the prior system. During the epidemic, the school administration assigns teachers by asking parents to supervise their children's education at home. Teachers are encouraged to take part in workshops that educate them how to develop engaging instructional movies that are also simple for pupils to grasp. Because of the Covid19 epidemic, it is possible that the current study may be a series of simulated experiences to sustain learning quality. Learning processes can be improved by combining the principal's managerial function, teachers' significant involvement in educating students, and parental assistance in supporting kids' learning at home.

\section{REFERENCES}

Abraukhova, V. (2020). Development of creative orientation of future teachers based on a research approach. E3S Web of Conferences, 210(Query date: 2021-08-05 01:41:18). https://doi.org/10.1051/e3sconf/202021018067

Adams, J. (2021). Understandings of creative practice and pedagogy by teacher education communities in West Bank, Palestine, and North West England. Discourse, 42(3), 408-424. https://doi.org/10.1080/01596306.2019.1708706

Adiguzel, F. B. (2021). Examining the creative drama-based lesson plans of the prospective turkish language and literature teachers. Eurasian Journal of Educational Research, 2021(91), 205236. https://doi.org/10.14689/ejer.2021.91.10

Al-Dababneh, K. A. (2019). The creative environment: Teachers' perceptions, self-efficacy, and teaching experience for fostering children's creativity. Early Child Development and Care, 189(10), 1620-1637. https://doi.org/10.1080/03004430.2017.1400969

Alea, L. A. (2020). Teachers' Covid-19 awareness, distance learning education experiences and perceptions towards institutional readiness and challenges. International Journal of Learning, Teaching and Educational Research, 19(6), 127-144. https://doi.org/10.26803/ijlter.19.6.8

Almarashdeh, I. (2016). Sharing instructors experience of learning management system: A technology perspective of user satisfaction in distance learning course. Computers in Human

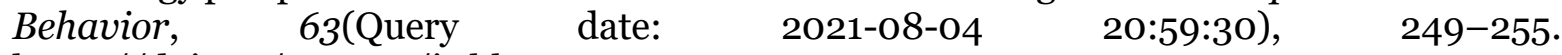
https://doi.org/10.1016/j.chb.2016.05.013

Amirova, A. (2020). Creative and research competence as a factor of professional training of future teachers: Perspective of learning technology. World Journal on Educational Technology: Current Issues, 12(4), 278-289. https://doi.org/10.18844/wjet.v12i4.5181

Banihashem, S. K., Farrokhnia, M., Badali, M., \& Noroozi, O. (2021). The impacts of constructivist learning design and learning analytics on students' engagement and self-regulation. Innovations in Education and Teaching International. https://doi.org/10.1080/14703297.2021.1890634

Barberà, E., Gómez-Rey, P., \& Fernández-Navarro, F. (2016). A cross-national study of teacher's perceptions of online learning success. Open Learning: The Journal of Open, Distance and e-Learning, 31(1), 25-41. https://doi.org/10.1080/02680513.2016.1151350

Barclay, C., Donalds, C., \& Osei-Bryson, K. M. (2018). Investigating critical success factors in online learning environments in higher education systems in the Caribbean. Information $\begin{array}{lll}\text { Technology for Development, } & \text { 24(3), }\end{array}$ https://doi.org/10.1080/02681102.2018.1476831

Ben, X. (2016). On the distance metric learning between cross-domain gaits. Neurocomputing, 208(Query date: 2021-08-04 20:59:30), 153-164. https://doi.org/10.1016/j.neucom.2016.01.098 
Bielousova, R. (2017). Developing materials for English for Specific Purposes online course within the blended learning concept. TEM Journal, 6(3), 637-642. https://doi.org/10.18421/TEM63-28

Bunga, B. N., Adu, A. A., Damayanti, Y., Takalapeta, T., Pello, S. Ch., \& Kiling, I. Y. (2021a). Synchronous vs. Asynchronous: Photovoice Study on Indonesian Youth's Online Learning Experience. Child \& Youth Services, 1-14. https://doi.org/10.1080/0145935X.2021.1901572

Bunga, B. N., Adu, A. A., Damayanti, Y., Takalapeta, T., Pello, S. Ch., \& Kiling, I. Y. (2021b). Synchronous vs. Asynchronous: Photovoice Study on Indonesian Youth's Online Learning Experience. Child \& Youth Services, 1-14. https://doi.org/10.1080/0145935X.2021.1901572

Chang, X. (2016). Application of virtual reality technology in distance learning. International Journal of Emerging Technologies in Learning, 11(11), 76-79. https://doi.org/10.3991/ijet.v11i11.6257

Creswell, John. (2007). Qualiitative Inquiry and Research Design. Sage.

Erbil, D. G., \& Kocabaș, A. (2018). Cooperative Learning as a Democratic Learning Method. Journal of Research in Childhood Education, 32(1), 81-93. https://doi.org/10.1080/02568543.2017.1385548

Feng, W. D. (2019a). Infusing moral education into English language teaching: An ontogenetic analysis of social values in EFL textbooks in Hong Kong. Discourse: Studies in the Cultural Politics of Education, 4O(4), 458-473. https://doi.org/10.1080/01596306.2017.1356806

Feng, W. D. (2019b). Infusing moral education into English language teaching: An ontogenetic analysis of social values in EFL textbooks in Hong Kong. Discourse: Studies in the Cultural Politics of Education, 4O(4), 458-473. https://doi.org/10.1080/01596306.2017.1356806

Gómez-Rey, P., Barbera, E., \& Fernández-Navarro, F. (2016). Measuring teachers and learners' perceptions of the quality of their online learning experience. Distance Education, 37(2), 146-163. https://doi.org/10.1080/01587919.2016.1184396

Hermanto, H., Marini, A., \& Sumantri, M. S. (2021). Studi Kebijakan Kepala Sekolah Dalam Pembelajaran Daring Bagi Siswa Sekolah Dasar di Era New Normal Pada Masa Pandemik Covid-19. Jurnal Basicedu, 5(3), 1502-1508. https://doi.org/10.31004/basicedu.v5i3.936

Hernández-Lara, A. B., \& Serradell-López, E. (2018). Student interactions in online discussion forums: Their perception on learning with business simulation games. Behaviour \& Information Technology, https://doi.org/10.1080/0144929X.2018.1441326

$37(4)$,

419-429.

Huang, Q. (2019). Comparing teacher's roles of F2f learning and online learning in a blended English course. Computer Assisted Language Learning, 32(3), 190-209. https://doi.org/10.1080/o9588221.2018.1540434

Iskandar, N. (2020). Development of student worksheets as online english learning media at the Indonesian vocational school. International Journal of Engineering Research and Technology, 13(11), 3819-3824.

Lang, S. N. (2020). Social Emotional Learning for Teachers (SELF-T): A Short-term, Online Intervention to Increase Early Childhood Educators' Resilience. Early Education and Development, 31(7), 1112-1132. https://doi.org/10.1080/10409289.2020.1749820

Martin, F., Wang, C., \& Sadaf, A. (2018). Student perception of helpfulness of facilitation strategies that enhance instructor presence, connectedness, engagement and learning in online courses. Internet and Higher Education, 37, 52-65. https://doi.org/10.1016/j.iheduc.2018.01.003

Miles, M. B., Huberman, A. M., \& Saldana, J. (2014). Qualitative data analysis: A methods sourcebook (p. 341). SAGE Publications, Inc.

Nguyen, T. V. S. (2019). English curriculum reform and formative assessment policies: Cross-case analysis-Implications for alternative assessment research in Vietnam. Using Alternative Assessment to Improve EFL Learners' Learning Achievement: From Theory to Practice, Query date: 2021-08-04 16:59:47, 23-40.

Oktaviani, 16422164 Anindita Yumnaa. (2020). Internalisasi Nilai-Nilai Pendidikan Islam Anak Usia Dini Melalui Pembelajaran Daring Di Masa Pandemi Covid-19 (Studi Kasus Pada RA Masyithoh Kauman Wonosobo Jawa Tengah). https://dspace.uii.ac.id/handle/123456789/28602 
Setyaningsih, K. D. (2020). Analisis Pelaksanaan Pembelajaran Jarak Jauh di SD Negeri Karangrena 03. Jurnal Riset Pendidikan Dasar (JRPD), 1(2).

Sulistiyo, U. (2020). Infusing moral content into primary school english textbooks: A critical discourse analysis. Indonesian Journal of Applied Linguistics, 10(1), 251-260. https://doi.org/10.17509/IJAL.V10I1.25067

Warsah, I. (2020a). Forgiveness Viewed from Positive Psychology and Islam. Islamic Guidance and Counseling Journal, 3(2), 2614-1566. https://doi.org/10.25217/igcj.v3i2.878

Warsah, I. (2020b). Jihad and radicalism: Epistemology of Islamic education at Pesantren Al-furqan in Musi rawas district. Jurnal Ilmiah ISLAM FUTURA, 1-18.

Warsah, I. (2020c). Religious Educators: A Psychological Study of Qur'anic Verses regarding alRahmah. Al Quds, 4(2), 275-298. https://doi.org/10.29240/alquds.v4i2.1762

Warsah, I. (2021). Islamic Religious Teachers' Efforts To Motivate Students And Implement Effective Online Learning. Edukasi Islami: Jurnal Pendidikan Islam, 1o(01), 383-383. https://doi.org/10.30868/ei.v10io1.1210

Warsah, I., Morganna, R., Uyun, M., Hamengkubuwono, \& Afandi, M. (2021). The Impact of Collaborative Learning on Learners ' Critical Thinking Skills. International Journal of Instruction, 14(2), 443-460.

Wei, H.-C., Peng, H., \& Chou, C. (2015). Can more interactivity improve learning achievement in an online course? Effects of college students' perception and actual use of a course-management system on their learning achievement. Computers \& Education, 83, 10-21. https://doi.org/10.1016/j.compedu.2014.12.013

Yazan, B. (2015). Three Approaches to Case Study Methods in Education: Yin , Merriam , and Stake Three Approaches to Case Study Methods in Education: Yin , Merriam ,. The Qualitative Report, 2O(2), 134-152. 